Cahiers $d u$ MONDE RUSSE

\section{Cahiers du monde russe}

Russie - Empire russe - Union soviétique et États indépendants

55/3-4 | 2014

Varia

\title{
Lucien Bianco, La récidive, Révolution russe, révolution chinoise
}

S.A. Smith

Q OpenEdition

Journals

Electronic version

URL: http://journals.openedition.org/monderusse/8063

DOI: $10.4000 /$ monderusse. 8063

ISSN: $1777-5388$

\section{Publisher}

Éditions de l'EHESS

\section{Printed version}

Date of publication: 1 July 2014

Number of pages: $400-406$

ISBN: 978-2-7132-2441-6

ISSN: $1252-6576$

\section{Electronic reference}

S.A. Smith, «Lucien Bianco, La récidive, Révolution russe, révolution chinoise », Cahiers du monde russe [Online], 55/3-4 | 2014, Online since 13 April 2015, Connection on 23 September 2020. URL : http://journals.openedition.org/monderusse/8063 ; DOI : https://doi.org/10.4000/monderusse.8063

This text was automatically generated on 23 September 2020

(c) École des hautes études en sciences sociales 


\title{
Lucien Bianco, La récidive, Révolution russe, révolution chinoise
}

\author{
S.A. Smith
}

\section{REFERENCES}

Lucien BIANCO, La récidive, Révolution russe, révolution chinoise, Paris : Éditions

Gallimard, 2014, 517 p.

1 The title of Lucien Bianco's magnificent study is not easy to translate into English: "The Recurrence" perhaps (as in the recurrence of a disease that has gone into remission) ; or better, "The Repeat Offence" (as in criminal recidivism). Pierre Nora apparently vetoed Bianco's original title: "La repetition," because of its theatrical connotations (it can mean a "rehearsal") ; and "La réplique," a word that can mean an "aftershock" as well as a "replica," was also considered. This, too, was rejected since aftershocks are always weaker than the initial earthquake. ${ }^{1}$ And this points us towards the nub of Bianco's argument. For against those on the left (especially in France) who once argued that Maoism marked a profound break with Stalinism, Bianco contends that Mao copied the Stalinist model, and that many of his supposed innovations were no more than exaggerations of features already present in the Stalinist original. In other words, Maoism was essentially a repetition of Stalinism and one, moreover, that in some ways was more destructive than the original. It is a bold, if not entirely original thesis, and Bianco elaborates it with subtlety and sardonic verve.

2 As the doyen of historians of the Chinese Revolution, Bianco is fully alert to the ways in which the nationalist character of that revolution distinguished it from the Bolshevik revolution, with its more universalistic, class character. In comparison with his most influential book, however, The Origins of the Chinese Revolution, which first appeared in French in 1967 and in a fourth edition in 2007, La récidive places much less emphasis on 
the indigenous factors that gave rise to the Chinese Revolution, stressing instead its essentially imitative dependence on the Soviet model. ${ }^{2}$ The core of his argument is that both revolutions were rooted in socio-economic backwardness and that the fundamental dynamic shaping their development was the determination on the part of the Communist rulers to catch up with the capitalist world, no matter what the cost to their populations. He argues that for Mao, the crucial lesson he learned from the Russian Revolution was the need to imitate Stalin's "Great Break," i.e. the decision in 1929 to launch crash industrialization and violent collectivization. This was the inspiration behind the Great Leap Forward (1958-1960). In contrast to recent tendencies to stress the determinacy of ideology, Bianco makes the case that it was the domestic and international pressure to overcome economic and social backwardness that was paramount in forging the similarities between the two regimes. While he does not deny the efficacy of ideology, his is, essentially, a structural account. At the same time, he tells us that though he was formed as a historian at a time when the Annales school was pre-eminent, he has always sought to preserve within himself the spirit of Plutarch. And his book is indeed constantly attentive to the importance of revolutionary actors.

3 The book comprises nine substantive chapters which deal, respectively, with backwardness, "catching up" economically, politics, peasants, famines, bureaucracy, culture, camps and "monsters." As this suggests, the scope is wide, but there are areas Bianco does not seek to cover. There is little about urban life or the working class (the leading class in the eyes of both regimes) or - a point to which I shall refer below - the Cultural Revolution. Given the theme of the book, moreover, we learn nothing about how the practices and language of Stalinist politics were brought to China by Chinese Communists trained in the Soviet Union before 1949 or by Soviet experts coming to the PRC in the 1950s. Nevertheless the sweep of the comparison is impressive. In the first two chapters, Bianco shows that China in 1949 was far more backward socio-economically than Russia in 1917, and draws attention to differences as well as similarities in patterns of socio-economic development. Urbanization in the Soviet Union, for example, advanced far more rapidly and spontaneously than in China. Both regimes improved the health and education of the populace, but he reckons the improvement was greater in Mao's China than Stalin's Soviet Union. Yet notwithstanding the CCP's more positive view of the peasantry, by the time Mao died in 1976, the average income of rural dwellers was scarcely one-third that of urban dwellers and possibly inferior to that of their grandparents. In the chapter on politics Bianco argues that Mao was basically ignorant of marxism, familiar only with the Stalinist style of politics. He scorns the idea that the mass line ever meant more than an authoritarian top-down mobilization of the masses. Yet he gives credit to Mao for recognizing the possibility of a new state-capitalist class coming to power through the institutions of the party-state. It is on this ruling class that the chapter on bureaucracy focuses. Bianco stresses the accumulation of privileges by the ruling elite in both societies, showing that Mao was far less tolerant of displays of privilege and material comfort than his mentor, yet arguing that it was essentially the work-style of the party elite to which he objected, rather than its monopoly of power.

4 Two outstanding chapters on the peasantry and on famine follow. Bianco tells the appalling story of Soviet collectivization well. Only the export of agricultural produce could pay for rapid industrialization and it was the need to extract more from the peasantry that was the spur to forced collectivization in 1928. He makes the perceptive point that Soviet collectivization was distinguished from its later Chinese counterpart 
by the simultaneous liquidation of private farms and the elimination of the kulaks as a class. It was this that ensured collectivization in China was relatively non-violent when the "socialist high tide" of 1955 was proclaimed. True, this was a result in part of the fact that the CCP had a far more detailed apparatus of rule in the countryside than had the Bolsheviks in 1928, but the fact that "rich peasants" - much reduced in status by land reform - were allowed to become members of the cooperatives meant that they escaped the murder, banishment and imprisonment suffered by their Russian counterparts. In both countries collectivization was the prelude to a harrowing famine, the prime causes of which were the ruthless pumping of resources from the agricultural sector to support a reckless rate of industrial growth, exacerbated by the ruthlessness and ignorance of the two dictators. Bianco follows Andrea Graziosi in suggesting that from autumn 1932 Stalin used famine to punish the Ukrainian people for their nationalist insolence, which is by no means an uncontroversial view. ${ }^{3}$ It leads to the debatable claim that Stalin's responsibility for the famine sprang from intention whereas Mao's sprang from delusion.

5 The chapter on culture, one of the longest in the book, is consistently interesting but ultimately unsatisfactory. Bianco wrestles with his preference for Soviet over PRC literature and he seems unwilling to concede that Soviet culture was never blighted to the same extent as culture under Mao. Despite his recognition of the problem of evaluating writers in terms of whether they were supporters or critics of the regime, he tends to articulate his analysis in terms of this principle. He thus cannot accept that a writer such as Mikhail Sholokhov - a craven Stalinist or Soviet patriot, depending on one's point of view - can have been a great writer. More importantly, perhaps, the limits of comparative method are most apparent when it comes to comparing writers, for whom individuality is the defining characteristic. To compare Evgenii Zamiatin and Shen Congwen, for example, by suggesting that both were writers who struggled to keep their distance from politics, is to seize on a shared quality yet to overlook the massive contrast in their genres and styles.

6 By contrast, the tightly focused chapter on the camps is an exemplary piece of comparative history, admirably illuminating the similarities and differences between the gulag and the laogai. Nearly 20 million Soviet citizens passed through the prison system between 1929 and 1955 - perhaps one in six adults - and nearly 6 million others were deported to distant regions. The proportion of those detained in China's camps and prisons was considerably smaller, reaching a maximum of 1.75 per cent of the population in 1952 and $1.05 \%$ in 1977. The camps in the PRC were smaller in size and their populations more stable. The social profile of the inmates in the two states, moreover, was also different, with the proportion of peasants, foreigners and possibly women (wives of "enemies of people") greater in the Soviet Union. As Bianco grimly demonstrates, however, the central experience of the gulag and the laogai was a common one of hunger and poor hygiene (possibly worse in the laogai), with guards equally corrupt but apparently more cruel in the gulag than the laogai.

7 The final chapter is a brilliant comparison of Stalin and Mao in terms of their personalities and modes of rule. Both dictators, according to the author, were cruel and inflexible, inflicting untold suffering on their peoples ; both were cut off from society ; both sought to make sense of the world and hankered to become major theoreticians. Stalin read much, assimilated quickly, and had considerable knowledge of several areas, whereas Mao was more narrowly Chinese in his intellectual formation - at the 
age of sixteen he had never heard of the United States - and his educational handicap increased with age, as he fell back for inspiration on the traditional classics. Bianco then embarks upon what he calls "the impossible demonstration" : namely, an attempt to judge which of the two "monsters" of the chapter title was worse. Given his central thesis, he concludes somewhat surprisingly that it is the 'recidivist' who comes out better from the comparison. He points out that a greater proportion of the Soviet population fell prey to the Great Terror than did Chinese to Cultural Revolution, a comparison that is still to the detriment of the Soviet Union even if 30 million Chinese peasants who perished in the famine of 1969-1961 are included. And whereas Stalin unleashed the Great Terror after declaring that socialism had triumphed, Mao saw the Cultural Revolution as about saving the revolution (although that point looks less telling if one takes into account the fact that the Soviet Union was threatened by external enemies in 1937 in a way that China in 1966 was not). Bianco's argument, however, rests ultimately on the motivations and modalities of rule of each tyrant. "On the one hand, a premeditated massacre, rigorous, bureaucratic control, a meticulous procedure launched and controlled by one man [...] on the other, power at a distance, overtaken by the cataclysm that it has unleashed and by the local initiatives for which it is responsible but which it is incapable of mastering" (p. 426). This contrast between ruination wrought wilfully and ruination wrought unintentionally is by no means clear, in my view. Some would argue that the Great Terror quickly ran out of Stalin's control, while others would point out that Mao regularly set quotas for the percentage of "counter-revolutionaries" to be arrested or put to death, long after the real danger of counter-revolution had receded. And it is stretching things to suggest that Mao's responsibility for the famine sprang from "folly", whereas Stalin's sprang from intent. Bianco does in fact mention that if Mao had not launched a "second leap" in summer 1959 - following his fury at Peng Dehuai's daring to criticise the Great Leap - two thirds of the famine victims might have been saved. And he concedes that Mao was "pushing things towards the abyss" (p.169). So it is hard to acquit him of a degree of intentionality (what Thomas Bernstein calls "wilfulness") in respect of the famine. ${ }^{4}$ And whilst Bianco is correct to say that Stalin's cruelty was more meticulous and vigilant than Mao's, it is doubtful whether any metric for measuring evil can be constructed that will prove to general satisfaction that Mao's cold indifference to the consequences of his actions was less morally culpable than Stalin's cold calculation. So while the comparison is a real tour de force, it is not clear that seeking to decide who was the worse "monster" is ultimately illuminating.

Throughout the book, Bianco, an expert on China, displays a strong command of the historiography of the Stalin era in English and French. ${ }^{5}$ This historiography, based on deep archival research, is much more extensive than the corresponding historiography of the PRC. Nevertheless, there is a nascent, archivally-based historiography of the PRC, of which Bianco makes surprisingly little use, except in relation to the famine. This matters because the archives allow us to compare in a way that was impossible until recently the impact of the two revolutions on the lives of ordinary people. Archival sources allow us to explore the two revolutions "from the bottom up"; and from that perspective differences start to appear as significant as similarities. To make just two very general points. First, the distinctive facets of Maoist ideology had a purchase on grass-roots politics that made the Chinese revolution very different for its Soviet counterpart. If recent Soviet historiography has tended to highlight once unnoticed aspects of Stalinism that appear to adumbrate Maoism - one thinks of the regular 
recourse to campaigns or the rituals of criticism and self-criticism within the party there was nothing similar in the Soviet Union to the ways in which Mao's shifting thought translated into the politics of everyday life. Following his speech on handling contradiction of February 1957, for example, a new round of struggle sessions and writing of personal histories was launched in workplaces around the country with a view to identifying antagonistic and non-antagonistic contradictions in the workforce. Similarly, in the mid-1960s, the exalted status of Mao Zedong Thought led to hundreds of thousands of educated youngsters being sent into villages to teach peasants to memorize Mao's "three constantly read articles," which dealt, respectively, with serving the people, communist internationalism, and perseverance in the face of hardship. In the Soviet Union, of course, there was mass propaganda aplenty, but nothing akin to such sustained and massively resourced campaigns aimed at reworking the beliefs and values of ordinary people in accordance with the shifting ideology of the Great Helmsman. If ideology was far more invasive of daily life in China than the Soviet Union, new archival sources also attune us to the ways in which indigenous cultural practices shaped official policy and popular response to those policies. When work teams were sent into villages to carry out land reform, for instance, they promoted the technique of "speaking bitterness," selecting poor peasants to pour out their grievances and denounce their "exploiters" in the new language of class. In 1947 in one district of Huanghua county in Hebei province, 323 peasants spoke of how they had starved in the "old society" ; 546 told of how they had begged for food ; 115 of how they had been forced to sell sons and daughters; 42 of how their families had been dispersed; 116 of relatives who had been killed by bandits. This venting of suffering was suffused with extremes of emotion. The local party organisation reported that among 5184 peasants who performed "speaking bitterness," 4451 cried bitterly, 12 cried until they fainted, 195 cried until they vomited. ${ }^{6}$ This theatricalization of politics was at the heart of all Maoist campaigns and it drew on the manichean story lines of much popular culture. In the public trials that accompanied the campaign against counter-revolutionaries in 1950-1951, the accused were assigned roles akin to those of sinister characters in folk opera and their crimes were narrated according to the conventions of that genre. On 20 May 1951, Peng Zhen, the mayor of Beijing, addressed a crowd of tens of thousands who had turned up for the trial of 220 counter-revolutionaries: "What shall we do with this bestial group of vicious despots, bandits, traitors, and special agents ?," he railed. "Shoot them !" the audience yelled. The show trials of 1936-37 in the Soviet Union were certainly orchestrated to theatrical effect, yet there was nothing akin to the participation of the masses in the drama or to the manipulation of folk genre to elicit emotional identification on the part of spectators. While we should certainly not assume that the Maoist state had the capacity to achieve its ends, its inventiveness in devising forms through which it could disseminate its ideological categories, its systems of classification, its discursive practices, its norms and values had no antecedent in Stalinism.

9 It is in the inattention to the Cultural Revolution, however, that one feels Bianco's thesis of recidivism most obviously fails to register the differences between the two revolutions. The Cultural Revolution is discussed only as a comparator to the Great Terror, and that discussion only takes up fourteen pages. Yet western scholars now tend to concur with their PRC colleagues in seeing the Cultural Revolution as lasting an entire decade, from 1966 to 1976. As a political crisis engineered by the supreme leader through the mobilization of Red Guards and rebel workers, a mobilization that quickly 
imperilled the regime over which he presided, the Cultural Revolution had no analogue in any other Communist state. So one might argue that to exclude it from the comparison with the Soviet Union is legitimate. Yet if one is seeking to understand what the Maoist revolution meant for hundreds of millions of people, then the Cultural Revolution was a defining experience. The mass movement to assault "those in authority taking the capitalist road" rapidly degenerated into violence, factionalism and chaos that deeply affected popular understandings of what the revolution was about. Not a state office, party organ, high school, university, factory or shop remained untouched, and even in the countryside the impact was much greater than was once thought, especially in county towns. In the Soviet Union there was nothing similar to the "wild beatings and wild killings" that tore local communities apart during 1967 and 1968, despite the violence of the civil war and collectivization, (indeed many Soviet citizens supported Stalin precisely because they saw him as the guarantor of social order). The Cultural Revolution thus reminds us that an indispensable element in any comparison between the two revolutions must encompass social history, must explore the differential impact of the revolution on the mass of the population.

Bianco's focus on the structural dynamics and top-down policies of the two regimes makes for a cogent case that, in formal terms, the revolutions were broadly similar. The emphasis on form, however, comes at the expense of attention to ideological and socio-cultural content; and once one starts to look "from the bottom up" at how the revolutions worked themselves out in the daily lives of ordinary people, then differences loom large. This criticism, however, is a response to the thought-provoking character of Bianco's argument and is not intended to detract from his extraordinary achievement. He has written a wise and humane book, one attuned to the ironies of revolution, a testament to a lifetime of study and reflection.

\section{NOTES}

1.

http://www.histoire.presse.fr/actualite/portraits/lucien-bianco-mao-lignemire-01-11-2014-118116. Last accessed 26 December 2014.

2. Lucien Bianco, Les origines de la révolution chinoise, P.: Gallimard, 1967. The first English edition appeared in 1971.

3. Andrea Graziosi, L'Urss di Lenin e Stalin : Storia del'Unione Sovietica, 1914-45, Bologna : Il Mulino, 2007, 361.

4. Thomas P. Bernstein, "Mao Zedong and the Famine of 1959-60 : A Study in Wilfulness," China Quarterly, 186, (2006) : 421-45.

5. Bianco's errors are tiny and few. It's doubtful, for example, that agriculture in late-imperial Russia may be described as "stagnant" (p. 20) ; or that kul'turnost' may be construed as ersatz culture or philistinism (p.113); and Zhdanov's father was a biblical scholar who became an inspector of schools, not a famous pianist (p. 307).

6. Hebei tudi gaige dang'an shiliao xuanbian [Selected Archival Materials on Land Reform in Hebei] (Shijiazhuang, 1991), 163-4. 
7. Michael Schoenhals, ed., "Public Security in the People's Republic of China: A Selection of Mood Assessment Reports (1951-1962)," Contemporary Chines Thought, 38, 3 (2007).

\section{AUTHORS}

S.A. SMITH

All Souls College, Oxford 